\title{
ENERGETSKA TEKMA ZA ARKTIKO
}

\section{ENERGY RACE FOR THE ARCTIC}

Povzetek Arktika je podvržena podnebnim spremembam, ki odkrivajo njen energetski, politični in gospodarski potencial in jo spreminjajo v novi Orient. Energetski viri, ki se skrivajo pod Arktičnim oceanom, lahko podaljšajo življenjsko dobo držav, ki so odvisne od nafte. Brez razvoja držav in tehnologije, ki bi nadomestila svetovno odvisnost in vedno hitrejšo porabo nafte, ostane edina rešitev iskanje novih virov energije. Arktika ponuja možnost, a brez ustrezne vrtalne tehnologije je dostopnost do virov nemogoča. Številna vprašanja ob tem ostajajo odprta. Ali bodo geopolitični interesi krojili prihodnost Arktike in s tem akterjev? Ali so države zmožne rešiti spore miroljubno? Povečana vojaška prisotnost ne kaže na mirno prihodnost, sploh s povečano napetostjo med Rusijo in ZDA.

Ključne Arktika, energetski viri, epikontinentalni pas, ekonomska cona, mednarodno besede sodelovanje, tehnologija.

Abstract The Arctic is subjected to climate changes, which are revealing its energy, political and economic potential, and are turning it into the new "Orient". Energy resources hidden beneath the Arctic Ocean can extend the lifespan of the countries dependent on oil. Without further development of countries and the technology to substitute global dependence and the increasingly fast oil consumption, the only solution remaining is the search for new energy resources. The Arctic offers this possibility; however with no adequate drilling technology, the access to resources is impossible. Several questions still remain open in this respect. Will the geopolitical interests shape the future of the Arctic and, consequently, the actors? Are the countries able to resolve conflicts in a peaceful manner? Increased military presence in the Arctic indicates a not so peaceful future, especially due to the increased tensions between Russia and the United States.

Key words Arctic, energy resources, continental shelf, economic zone, international cooperation, technology 


\section{Uvod Arktika in njeni potenciali}

Arktična regija $\mathrm{v}$ zadnjih letih predstavlja pomemben geopolitični interes držav, ki iščejo nove vire energije. $Z$ vedno večjo potrebo po novih virih energije, potencialom Arktike (13\% svetovne nafte in $30 \%$ neizkoriščenega plina) ter novimi zemljiškimi zahtevki po arktičnem ozemlju vlada strah pred novimi energetskimi konflikti. Možnosti novega raziskovanja omogočajo podnebne spremembe, ki topijo arktični led z zaskrbljujočo hitrostjo, in dostop do ozemlja, ki je bil prej prekrit z ledom ter popolnoma nedostopen. Cilj tekmovanja med državami je upanje najdbe novih, neizkoriščenih virov, s katerimi bi si država lahko povečala moč in bogastvo v mednarodnem okolju. Kot sredstvo v tekmovanju so države posegle po porasti vohunske dejavnosti in povečanju vojaške prisotnosti v regiji. Do zdaj je konflikt precej omejen, saj je večina odkritih in dostopnih virov znotraj suverenih območij sosedskih držav, vendar se tveganje konfliktov povečuje sorazmerno s topljenjem ledu, saj so možnosti odkritja na spornih conah vedno verjetnejše. Arktične države, kot so Rusija, Združene države Amerike (ZDA), Norveška, Kanada, Švedska in Danska, želijo uresničevati svoje energetske interese na istih predelih arktičnega ozemlja. Nekateri varnostni analitiki obravnavajo situacijo na Arktiki kot zamrznjeni konflikt (frozen conflict), saj je poleg vedno večje skrbi za okoljsko varnost glede višine ledu skupaj z aktualnimi napetostmi med Zahodom in Rusijo (Krim, Sirija itn.) eskalacija mogoča v vsakem trenutku.

Prav zaradi energetskega potenciala postaja arktična regija novo igrišče za geopolitične interese in hkrati ustvarja tekmovanje med interesenti, državami, ki mejijo na regijo. Zmanjševanje zalog energetskih virov na globalni ravni je privlačil poglede držav na regijo, ki je na prvi pogled nezanimiva in težko dostopna (75 odstotkov zemlje je neustreznih za bivanje in prekritih z ledenimi formacijami, debelimi do tri metre. Javnost in oblikovalci politik si na neki način še vedno ne priznavajo, kako odvisnost od energentov, na primer nafte in plina, vpliva na potek vsakdanjega življenja in kaj se bo zgodilo, ko bodo trenutna energetska nahajališča izčrpana. Brez ustreznega načrta za zmanjševanje odvisnosti in vlaganja $\mathrm{v}$ alternativne vire bodo države in njeni prebivalci v nepredstavljivem položaju, v katerem bodo gospodarstvo, zdravstvo, vojska itn. popolnoma onemogočeni. To je vzrok, zakaj si države gradijo temelje na Arktiki za čas, ko bo podnebje stopilo led ali bo na voljo ustrezna tehnologija, ki bo prebila ledene formacije in bo Arktika lahko izpostavljena kot bogata regija, pripravljena na izkoriščanje bogastva. V zadnjih letih se $\mathrm{v}$ medijih pojavljajo napovedi znanstvenikov, ki zaradi podnebnih sprememb napovedujejo talitev arktičnega ledu do leta 2030. Posledice tega bodo razkrile zaloge naravnih virov in povzročile ekološke spremembe, ki bodo lahko katastrofalne za celoten planet. Svetovne ocene naravnih virov lahko razvijejo intenzivnejše politične in vojaške napetosti med državami. Tudi pravne ureditve, s katerimi se regija trenutno upravlja, bodo z obljubo bogastva postale sredstvo subjektivnih interpretacij za doseganje določenih ciljev držav. 


\section{METODOLOGIJA}

Energenti predstavljajo bistvo in pogon sodobnega načina življenja, a so velikokrat prezrti kot grožnja človekovi, nacionalni in mednarodni varnosti. Tema ni visoko uvrščena na dnevnem redu $v$ mednarodnih varnostnih organizacijah, saj je problematika energentov prezrta, dokler ne pride do konkretne grožnje, ko je škoda že storjena in ni več možnosti za rešitev brez posledic. Članek obravnava eno izmed žarišč spora v povezavi z energenti, ki jo predstavlja Arktika. Problematika Arktike je, da jo v mednarodni skupnosti ne obravnavajo kot varnostno vprašanje. Čeprav v regiji še ni bilo resnih sporov, lahko ob izčrpanju trenutnih virov energentov preraste v obsežen mednarodni konflikt.

Razlage problematike se bom lotila z geopolitično teorijo, ki jo v mednarodnih oblikovalci politik odnosih velikokrat prezrejo, a nam omogoča vpogled v skrite interese sodobnih držav. Prav tako se bom kritično lotila branja in analize primarnih in sekundarnih virov ter oblikovala objektivno analizo problematike arktične regije. Najprej se bom osredotočila na vzroke možnega konflikta, akterje, interese in motivacijo. Nato bom obravnavala pravne utemeljitve držav do arktičnega ozemlja in predstavila vsako državo, njene interese na arktičnem ozemlju ter možne konflikte.

Glavni cilji članka so pridobitev odgovorov na vprašanja: Kdo so glavni akterji, ki bi lahko povzročili izbruh konflikta? Ali so možnosti, da se države razdelijo v blokovsko ureditev? Navsezadnje bom skozi celoten članek poskušala predstaviti in $\mathrm{v}$ zaključku rešiti možne prihodnje scenarije $\mathrm{z}$ odgovorom na hipotezo: »Na podlagi preteklih dogodkov in obljube bogastva $\mathrm{v}$ lastništvu arktičnih energentov si bodo države poskušale na silo z vojsko zagotoviti čim večje lastništvo arktičnega ozemlja.« Zaradi gospodarske koristi, ki jo obljublja Arktika, jo lahko označimo kot novi Orient, saj bo omogočala precejšnji dobiček. Hkrati postaja pomembno žarišče konflikta in prihodnjih vojaških operacij.

\section{TEORETIČNO IZHODIŠČE ZA PREUČEVANO TEMO}

Geopolitika ima močan vpliv na posameznikovo nacionalno in mednarodno varnost ter na blaginjo držav. Pri energentih so države v precepu zaradi njihove neenakomerne porazdelitve po svetu, zato je trgovina ali tekmovanje za energenti del dolgoročnih zgodovinskih in kulturnih odnosov, ki imajo močan vpliv pri eskalaciji konfliktov in geopolitičnih interesov, ki trajno zavezujejo odnose in sodelovanje med vključenimi akterji, saj vzpostavljajo »neprebojno« soodvisnost. Geopolitična teorija nam omogoča razumevanje, kako geografski dejavniki oblikujejo pretekle ali prihodnje konflikte, s čimer se povečuje pomen geografije za politične odločitve oblikovalcev politik. Predvsem poudarja gospodarske, okoljske, diplomatske in varnostne odnose med nacionalnimi državami ter mednarodnimi vladnimi in nevladnimi organizacijami ter vključuje lokacijsko opredelitev nacionalnega ali večnacionalnega ozemlja; opisuje vse karakteristike ozemlja; razpoznavanje nacionalnega ozemlja neke 
države od drugih držav; opredelitev kulturne cone ali civilizacije; in oblikovanje ter vplivanje na zgodovinski razvoj držav (Chapman, 2011).

V literaturi se na splošno priznava, da se je izraz geopolitika prvič uporabil leta 1899 v članku revije Ymer švedskega politologa Rudolfa Kjellena (1864-1922). Pozneje je Kjellen leta 1905 uporabil nemški izraz Geopolitik v nemški reviji Geographische Zeitschrift. Geopolitiko je opredelil kot vlogo geografskih dejavnikov pri določanju nacionalnega vedenja. Čeprav je izvajanje geopolitike že dolgo del zunanje politike nacionalnih držav, se je njen vzpon kot znanstvene discipline in formaliziranega vladnega instrumenta pri oblikovanju politike začel komaj v začetku 20. stoletja. Poleg politične povezanosti gre za koncept, ki hkrati vključuje teme, kot so demografska gibanja, gospodarski razvoj, raba zemljišč in distribucija naravnih virov. Glavni poudarki geopolitike vključujejo: države imajo svoje meje, prestolnice, komunikacijske linije, vrednote in kulturo; velikost države in viri določajo njeno moč v mednarodnem okolju; in države so v nenehnem tekmovanju, pri čemer večje države poskušajo neprestano širiti in utrjevati svojo moč (po Chapman, 2011, str. 7).

Največ pozornosti je bila geopolitika deležna po prvi in drugi svetovni vojni ter po letu 1991, ko je Sovjetska zveza (v nadaljevanju SZ) razpadla in se je tako končalo bipolarno obdobje (blokovska razdelitev med ZDA in SZ) hladne vojne. Konec blokovske razdelitve je pospešil tekmo za prostor in interesne sfere v mednarodni skupnosti. S tem se je izraz geopolitike začel izpostavljati kot sinonim za tako tekmo v notranji in zunanji politiki nacionalnih držav (Parker, 1997). Opredelitev geopolitike ni enotna in je podvržena posamezni interpretaciji. Pri opredelitvi politologa Rudolfa Kjellena se prostorske značilnosti nanašajo na geografske fizične dejavnike in njihov odnos do politične moči, veliko drugih geopolitičnih mislecev (npr. Foucher, 1946 in de Gaulle, 1890-1970) priznava pomembnost tudi drugih dejavnikov znotraj geopolitike, kot so varnost, obramba, vojska in gospodarstvo. Eden izmed dejavnikov geopolitične strategije je izkoriščanje lastnih geografskih priložnosti in geografske ranljivosti njegovih nasprotnikov (Simoniti v Parker, 1997).

\section{ARKTIČNI NARAVNI VIRI}

Arktika predstavlja geopolitični interes zaradi odkritih naravnih virov in obljube po odkritju novih virov energentov. Arktični ocean je bil do pred nekaj leti v celoti zajet $\mathrm{v}$ led, podnebne spremembe, ki so povzročile njegovo obsežno taljenje, so omogočile dostop za plovbo in hkrati razkrile njegov potencial v bogastvu naravnih in živalskih virov (Chapman, 2011). Zaradi obsežnega in raznolikega interesa je pomembno, da je regija geografsko opredeljena. Za opredelitev Arktike je več definicij. Najenostavnejša definicija je: »/r/egija, ki leži severno od polarnega kroga ali najsevernejše meje rasti drevesa« (Bailey, 2009, str. 12). Zaradi različnih interesov različnih akterjev tudi definicija regije ni enotna med akterji in je stvar interpretacije. Geografsko arktična regija obsega območje Arktičnega oceana in kopenskih območjih v nekaterih delih Kanade, Finske, Islandije, Norveške, Rusije, Švedske, Danske (z Grenlandijo) in ZDA z Aljasko (Heininen, 2009; U.S. Department of Commerce, 
2013). S tem Arktika zaseda okoli 15 milijonov $\mathrm{km}^{2}$ polarnega morskega ledu, ki se v poletnih mesecih zmanjša za približno 8 milijonov $\mathrm{km}^{2}$. Obstajajo le trije izhodi iz Arktičnega oceana: zahodno od Grenlandije v severnem Atlantiku, skozi ožino med Grenlandijo in Svalbardom in skozi Beringovo ožino med Chukotko in Aljasko (slika 1). Celotna regija je sestavljena iz edinstvenega ekosistema s številnimi vrstami, ki jih ne najdemo nikjer na svetu, in z velikimi zalogami naftnih in mineralnih rezerv, ki pritegujejo zanimanje različnih vlad in korporacij. Prav zato se povečuje pritisk akterjev v razvoju tehnologije, ki bi omogočila dostop do območij bogatih z naravnimi viri (The Pew Charitable Trusts, 2015). Nafta, plin, minerali, gozd in ribe so največji interes $\mathrm{v}$ regiji, ki je drugače prekrita z ledom. Glavno vprašanje je: »Ko se arktični led stopi, kdo ima pravico do njenih naravnih virov?« Mejne države so z željo in obljubo po dobičku vstopile v tekmovanje za njeno lastništvo nad čim večjim in bogatim delom zemlje. Trenutna proizvodnja nafte iz Arktične regije je približno desetino celotne svetovne proizvodnje in četrtino zemeljskega plina. Pri tem dominira ruska Arktika z okoli 80 odstotki proizvodnje nafte, sledijo ji Kanada, ZDA (Aljaska) in Norveška. Čeprav je nafta največja obljuba Arktike, ni edina dobrina, za katero tekmujejo države. Poleg neodkritih naftnih in plinskih virov ima Arktika tudi bogata nahajališča niklja, bakra, premoga, zlata, urana, volframa in diamantov, ki se še sploh niso začeli izkopavati zaradi nedostopnosti in visokih razvojnih stroškov. Obsežno območje je dom različnih vrst rastlin in živali. Ribe, kot sta na primer losos in trska, predstavljajo dragocen komercialni ribolov (Keil, 2007). Lastništvo energetskih virov je največji mogoč vir konflikta, vendar ni oziroma ne bo edini vzrok. Prav zaradi vseh naravnih in živalskih virov je arktična regija postala vir mednarodnega tekmovanja. Ocena Energy Information Administration (EIA) glede arktičnih energetskih virov je prinesla mešane občutke. Na eni strani je dobra novica, da ima Arktika približno še 22 odstotkov neodkritih naftnih virov in zemeljskega plina, ki temelji na oceni U.S. Geological Survey (USGS). Na drugi strani je slaba novica, da osnovni naravni vir na Arktiki predstavlja zemeljski plin, za katerega so prevozni stroški bistveno dražji (Chapman, 2011).

\section{KOMU KAJ PRIPADA? PRAVNE UTEMELJITVE}

Arktična regija je $\mathrm{v}$ zadnjih letih zaradi svojih bogatih naravnih virov in na novo prehodnih plovnih poti postala vir mednarodnega tekmovanja. Nestrinjanje pri razdelitvi ozemlja med sosedske države povečuje eskalacijo konflikta. Zaradi naravnih virov in plovnih poti je potrebna jasna razmejitev meja, ki ne sme biti dosežena z oboroženim konfliktom, temveč z mednarodnim pravom.

»Zakon morja je skupek strukture carin, pogodb in mednarodnih sporazumov, s katerimi vlade vzdržujejo red, produktivnost in miroljubne odnose na morju « (U.S. Department of Commerce, 2013). Arktična regija ni pravno utemeljena na zemlji, saj je skoraj njena celotna struktura sestavljena iz ledu in jo mednarodna skupnost obravnava kot morje. Ker ima regija poseben status, se je treba pri naslavljanju možnih konfliktov obrniti na pravne regulacije in njihovo opredelitev. Zaradi lažjega obravnavanja je $\mathrm{v}$ mednarodni skupnosti ta regija obravnavana kot mednarodne 
vode, ki omogoča akterjem lažji dostop. Pravne omejitve so pomembne, saj je regija »konfliktna« zaradi obsežnih naravnih virov in nekonvencionalnih terjatev ${ }^{1}$ do ozemlja. Pravno vprašanje statusa ledu na Arktiki je pod drobnogledom že več let in čez leta se je pojavilo več vprašanj kot odgovorov. Ampak lahko enačimo Arktični ocean z vsakim drugim oceanom in ga reguliramo pod pomorskim pravom? Pravne vede navadno regulirajo vodo v plinastem in tekočem stanju, Arktika je sestavljena iz ledu. Iz pravnega vidika ga lahko opredeljujemo kot glasies firma ${ }^{2}$ ali kot terra firma-res nullius ${ }^{3}$, ki je gledano kot državna last ali kot liberum-res communis ${ }^{4}$, s katerim ga nobena država ne bi mogla zavzeti kot državno last. Na koncu jo mednarodna skupnost opredeljuje kot morsko območje z izjemo (Cinelli, 2011, str. 7-8). Ampak če opredelimo ozemlje kot nikogaršnjo zemljo oz. terra nullius, ga država lahko okupira, če mednarodno pravo to dopušča. Nadzor in pristojnost nad ozemljem je treba določiti in ju pravno zagovarjati ter obvestiti širšo mednarodno skupnost za preprečitev prihodnjim napetostim (Georgescu, 2010, str. 44-47).

Konvencija Združenih narodov o pomorskem mednarodnem pravu (UNCLOS) ${ }^{5}$ določa pravila, ki urejajo »uporabo« oceanov, morij in njihovih virov. Sestavljen je iz 320 členov in 9 prilog, ki urejajo vse vidike uporabe oceanskega prostora. Arktičnim državam pripada 200 navtičnih milj ali 370 kilometrov (slika 1), gre za ekonomsko cono v Arktičnem oceanu, ki je opredeljena v skladu s 76. členom in je bila razširjena v aneksu II, ki pravi, da lahko države po ratifikaciji konvencije razširijo »/.../ zunanje meje svojega epikontinentalnega pasu zunaj svojih 200 navtičnih milj, /.../ po 10 letih po podpisu konvencije in s podporo znanstvenih in tehničnih podatkov« (UN Convention on the Law of the Sea, člen 4). Pet držav, ki obkroža Arktični ocean Kanada, Danska, Norveška, Rusija in ZDA - so lahko te zahtevke vložile leta 2013, 2014, 2006 in 2007, medtem ko v ZDA konvencije niso ratificirali in je ne priznavajo. Čeprav jo je Obamova administracija poskušala, do danes še niso zbrali dovolj podpore za njeno ratifikacijo (United Nations, 2013). Izjema v pravilu je 234 člen, ki vsebuje »kanadsko klavzulo«; klavzula je zapisana v osmem poglavju, ki obsega zaledenela območja v zvezi z zaščito in ohranitev morskega okolja in daje državam pravico »/.../ sprejetja in uveljavljanja nepristranskih zakonov in predpisov za preprečevanje, zmanjšanje in nadzorovanje onesnaževanja ladij v zaledenelih območjih v mejah ekonomske cone /.../ « (UN Convention on the Law of the Sea, člen 234). Implementacija konvencije je naloga Komisije za meje epikontinentalnega pasu (Commission on the Limits of the Continental Shelf-CLCS), ki določa spoštovanje zunanjih meja epikontinentalnega pasu in podaja priporočila za njeno razširitev onkraj 200 navtičnih milj (United Nations, 2013).

\footnotetext{
Ruska raziskovalna ekspedicija je leta 2007 zapičila rusko zastavo na morsko dno Severnega tečaja in si tako želela prisvojiti njegovo ozemlje.

Trd led.

Trdna zemlja, ki jo je mogoče lastiti.

Javna domena ali skupna dediščina človeštva.

5 Konvencija Združenih narodov o pomorskem mednarodnem pravu (United Nations Convention on the Law of the Sea ali Ustava oceanov).
} 
Zaradi strateškega pomena arktične regije in sodelovanja več evropskih držav se je Evropska unija (EU) vključila $\mathrm{v}$ sodelovanje $\mathrm{z}$ evropskimi arktičnimi državami, $\mathrm{s}$ podporno vlogo in kot pomoč pri spoprijemanju z izzivi, s katerimi se regija spoprijema pod neposredno grožnjo podnebnih sprememb. Njena podpora tako temelji na treh ciljih: zaščita in ohranjanje Arktike v sožitju z njenim prebivalstvom, spodbujanje trajnostne rabe virov in mednarodno sodelovanje. Hkrati se je arktična politika EU vzpostavila zaradi gospodarske vrednosti, saj je trg EU idealen kandidat za uvoz blaga z Arktike (Council of EU, 2014). Prelomno leto v razvoju arktične varnosti je leto 2007, ki je bilo v luči ruske »invazije« na Arktiko. S podvodnim raziskovanjem so odkrili in zavzeli ozemlje z velikim potencialom nafte, plina in mineralnega bogastva. Mednarodna skupnost je izrazila šok, da si Rusija želi povečati nadvlado v regiji, ki je v navzkrižju z UNCLOS. Posledično so se predstavniki Kanade, Norveške, Danske, Rusije in ZDA zbrali leta 2008 na Grenlandiji in se srečali z namenom določitve mej pod Severnim ledenim morjem. Rezultat srečanja je bil, da so vsi predstavniki podpisali deklaracijo Iluissati ${ }^{6}$. Dogovorili so se glede suverenosti v arktični regiji in kako bodo države $\mathrm{v}$ prihodnosti obravnavale učinke in boj proti podnebnih spremembam. V deklaraciji so potrdili, da še vedno ostajajo zavezani mednarodnemu pomorskemu pravu, a hkrati izrazili zastarelost konvencije, ki je bila sprejeta leta 1982. Kljub vsem ukrepom in srečanjem se bo o UNCLOS-u na novo razglabljalo v Varnostnem svetu komaj leta 2020. Prav tako je problem vzpostavitve upravljanja Arktike pod konvencijo, ker ZDA niso ratificirale UNCLOS-a. Vse dokler države ne bodo sprejele odločitev, imajo na področju Arktike skupno odgovornost (Arctic Governence Project, 2015).

Brez mednarodnega sporazuma med državami je na Arktiki mogočih več izbruhov konfliktov (slika 1, str. 98):

1. Lastništvo severozahodnega (SZ) $\operatorname{prehoda}^{7}$ (slika 2, str. 98). Čeprav si Kanada že lasti in druge države ne ogrožajo pravnega položaja Kanade nad omenjenim prehodom, bodo lastništvo prepustile Kanadi, le če je ta sposobna zagotoviti varnost prehoda (tihotapljenje ilegalnih substanc, nezakonitih priseljencev in teroristov) in okoljsko varnost. Glavna opozicija je ZDA, ki ne priznava teh vod za interne. Poleg ZDA imajo zahteve po različnih področjih vzdolž prehoda tudi Danska, Norveška in Rusija (Byers, 2013).

2. Lastništvo severovzhodnega (SV) $\operatorname{prehoda}^{8}$ (slika 2, str. 98). Čeprav je prehod trenutno pod ruskim nadzorom s presenetljivo malo vmešavanja iz drugih držav, je še vedno potencialno konfliktno območje zaradi drugih ruskih zahtevkov. Severna morska pot (angl. Northern Sea Route), kot jo imenujejo Rusi, je prihodnost mednarodne trgovinske poti. Pot skozi ta prehod bi zmanjšala razdaljo in stroške prevoza med Šanghajem in Hamburgom na le 14.000 km v primerjavi s potjo prek Sueškega prekopa, ki je dolga 20.000 km (Evers, 2013).

\footnotetext{
28. maja 2008 so jo sprejele arktične obalne države (ZDA, Rusija,Kanada, Norveška in Danska).

Prehod povezuje Atlantski in Tihi ocean prek Arktičnega oceana vzdolž severne obale Severne Amerike skozi različne poti v kanadskem arktičnem arhipelagu.

$\&$ Arktična ladijska pot povezuje Atlantski in Tihi ocean, ki prečka Arktični ocean po obalah Rusije in Norveške. Njegovo izkoriščanje se je začelo komaj poleti leta 2005, ko so podnebne spremembe povzročile prvo večjo otoplitev in topitev ledu na Arktiki.
} 
3. Povezovanje ZDA z drugimi državami v okviru arktičnega sveta ${ }^{9}$, da bi zadržale rusko osvajanje Arktike.

4. Lomosov hrbet, spor med Rusijo, Kanado in Dansko. Zahtevek po lastništvu podvodnega grebena je v epikontinentalnem zahtevku Danske in Rusije.

5. Otoki Hans, spor med Kanado in Dansko. Gre za ozemlje, ki ne kaže nobene posebnosti v smislu naravnih virov ali strateške pomembnosti.

6. Morje Beaufort, spor med Kanado in ZDA zaradi dogovora o morski meji.

7. Zahtevek Danske za lastništvo severnega tečaja. Prekriva se s kanadskim in ruskim zahtevkom.

Eskalacija problema se je $\mathrm{v}$ mednarodni skupnosti izpostavila zaradi ruskega »incidenta« leta 2007 in izpostavitve cryopolitics $^{10}$, pri čemer lahko politika moči vodi v novo hladno vojno. Pravni vidik se lahko upre negotovosti in vzpostavi diplomatska pogajanja, kajti najbolj pomembne rezerve virov so znotraj teritorialnih vod obalnih držav Arktike. Trenutno raziskave, ki bi določile, kaj se skriva v morskem dnu na območjih, na kateri se interesi držav prekrivajo, še niso mogoče, saj bo s trenutnim tehnološkim napredkom zaradi operativne zahtevnosti in potrebnih financ trajalo še desetletja, preden bodo te vode komercialno uporabne. Zaradi hitrejšega napredka se bodo države lotile mednarodnega javno-zasebnega sodelovanja, ki lahko zniža verjetnost meddržavnih sporov zaradi negativnega vpliva na komercialne dejavnosti. Zgodovinsko gledano lahko pravni vidik s sporazumi obdrži mir v regiji. V preteklosti smo že bili priča pogajanja med SZ, pozneje Rusijo, in Norveško za mejo na Barentsovem morju, kjer so po 40 letih konflikt rešili sporazumno in miroljubno. Tudi v času hladne vojne sta državi vzpostavili sporazum o ribolovu, prav tako na spornem območju med državama. Trenutno lahko zaostanki pri stališčih, ki čakajo na obravnavo v CLCS, trajajo do leta 2020, a na srečo ne pomenijo večje možnosti konfliktov (Koivurova, Kapyla in Mikkola, 2015). Kljub temu v arktični regiji poteka energetska tekma, v kateri je eskalacija konflikta, kot nam dokazujejo zgodovinski dogodki, zelo verjetna.

\section{5 ŽARIŠČA KONFLIKTOV V ARKTIČNI REGIJI}

Vsaka država ima drugačno zgodovinsko ozadje pri vpletanju v arktično regijo, zato ima tudi vsaka država drugačen pristop do današnjih teritorialnih, ekonomskih in varnostnih interesov. Na zunaj je videti, kot da nobena država nima večje prednosti v arktični tekmi, toda nekatere države so si zagotovile hitrejši start.

\footnotetext{
- Ustanovljen je bil leta 1996 z Ottavsko deklaracijo. Svet si prizadeva za spodbujanje sodelovanja in posvetovanje med državami članicami, s posebnim poudarkom na vprašanjih trajnostnega razvoja, varstva okolja in ljudi. Članice so ZDA, Rusija, Danska, Švedska, Kanada, Finska, Islandija in Norveška. Leta 2013 so se jim še pridružile Kitajska, Japonska, Indija, Italija, Singapur in Južna Koreja.

${ }^{10}$ Tekmovanje med državami za obvladanje nastajajočih naravnih virov in ozemlja s taljenjem na področjih, kot je Arktična regija ali Antarktika.
} 


\subsection{Združene države Amerike}

ZDA kot svetovna velesila zgodovinsko gledano niso bile prisotne na Arktiki. Njihovo ozemlje $v$ regiji je opredeljeno kot območje nad arktičnim krogom in obsega sever Aljaske in dele morij Beaufor in Chukchi. Ne morejo se enačiti s Kanado in Rusijo, ki uporabljata Arktiko kot temelj nacionalne identitete, kar ZDA ni bilo treba. Večinoma so jo uporabljale le kot del zagotovitve nacionalne varnosti pred oboroženimi napadi. Tako so ZDA v drugi svetovni uporabljale arktične poti po morju in zraku za dostavo potrebnih sredstev na sovjetsko fronto ter posledično za obrambo pred napadom Japonske. Na pobudo predsednika Eisenhowerja so med hladno vojno zgradili tudi opozorilni sistem in nadzor pred zračnim napadom z vključenimi kontinentalnimi obrambnimi radarji (po Conley, 2012, str. 18). A kljub temu so ZDA s poznim startom in zavrnitvijo ratifikacije UNCLOS-a slabo pripravljene na Kanado, Rusijo, Dansko, Islandijo, Norveško, Švedsko in Finsko, ki so že vse dobro pripravljene na zahtevek dela arktičnega ozemlja z različnimi nacionalnimi strategijami in pravnimi utemeljitvami. Njihovi interesi so se komaj jasneje začeli pojavljati, ko je National Security Council (2009) sprejel Nacionalno varnostno predsedniško direktivo (National Security Presidential Directives NSPD) št. 66, v kateri je navedeno, da so »Združene države Amerike arktični narod z različnimi in prepričljivimi interesi v regiji« (NSPD, 2009, II). V njej so opredeljeni najbolj pereči varnostni interesi ter obravnava upravljanje, znanstveno sodelovanje, okoljska vprašanja, meje in gospodarski razvoj. Njen glavni namen so »razvoj večje zmogljivosti in zaščita državnega zračnega prostora, zemlje in morskih mej $\mathrm{v}$ arktični regiji /.../ ter ohranitev mobilnosti ameriške vojske in civilnih plovil po vsej arktični regiji /.../« (NSPD, 66. člen). Ker arktično ozemlje predstavlja del varovanja pred raketnimi napadi, so njeni interesi tudi v namestitvi raketnih obramb in zgodnjega opozarjanja (NSPD, 2009, II). Leta 2013 je ameriško ministrstvo za obrambo v svoje strateške dokumente vključilo ameriške interese v regiji, ki se nanašajo na sedanja in prihodnja dogajanja na Arktiki. Zaradi novih izzivov in priložnosti, ki jih regija ponuja, so hkrati sprejeli nacionalno strategijo za arktično regijo, ki opredeljuje in povzema ameriške interese nacionalne varnosti, katero prizadevanje je odgovorno upravljanje regije in krepitev mednarodnega sodelovanja (United States Government, 2013).

ZDAimajo tri glavne interese na Arktiki. Prvi so teritorialni interesi, katerih uresničitev je težka zaradi nepriznanja UNCLOS-a. Čeprav je UNCLOS v ZDA zdaj priznan kot kodifikacija mednarodnega prava, brez ratifikacije nimajo pravne osnove, ki bi preučila in zaščitila njihove ozemeljske pravice in zahteve po epikontinentalnemu pasu Aljaske. Prvi teritorialni interes je ob obali Kanade in drugi vzdolž obale Rusije (slika 2). Gre za prehoda, ki predstavljata bližnjico za trgovino z Daljnim vzhodom in tako postajata resen konkurent Panamskemu in Sueškemu prekopu. Nesoglasje pomeni želja ZDA, da prehoda spadata pod mednarodne vode, Rusija in Kanada pa se borita za obravnavo teh prehodov kot teritorialne vode, s čimer bi imeli nad njima suverene pravice (Carlson in drugi, 2009, str. 34-38). Teritorialni interesi se prekrivajo z gospodarskimi (nova najdišča nafte in zemeljskega plina), saj so ZDA močno odvisne od uvoza nafte, ki ga želi Obamova administracija zmanjšati za 
tretjino do leta 2025. Rezerve, ki jih skriva Arktika, pomenijo rešitev za ameriško naftno porabo in energetsko odvisnost od Bližnjega vzhoda. Trenutno črpanje iz aljaških naftnih vrtin pokriva 17 odstotkov celotne ameriške porabe (Keil, 2011). Poleg nafte in zemeljskega plina je Arktika polna zalog niklja, železove rude in drugih redkih zemeljskih mineralov. Za ZDA je rudarstvo zelo pomembno, saj je Aljaska znana po rudniku premoga in cinka, imenovanega »red dog« (10 odstotkov svetovnega cinka). Tretji so varnostni interesi in izzivi, s katerimi se bo Arktika spoprijela v prihodnosti, kot so podnebne spremembe, piratstvo, terorizem, zaščita meja in odzivi na nesreče (po Conley in drugi, 2012, str. 1). Varnostni interesi so opredeljeni v nacionalni predsedniški direktivi in vključujejo mehanizme zgodnjega odkrivanja groženj, strateško odvračanje, prisotnost mornarice in obalne straže ter svobodo plovbe in preleta. Znotraj domovinske varnosti sta pomembni zaščita pred terorističnimi napadi in ublažitev sovražnih dejanj, ki povečujejo ranljivost ZDA na Arktiki (po Conely in drugi 2012, str. 20). Kot ugotavlja Conley, je perspektiva za obrambo pred raketnimi napadi prednostna naloga na področju varnosti za ZDA. Cilj je razviti celovit in večplasten sistem obrambe pred balističnimi izstrelki na arktičnem ozemlju (vojaške letalske baze: Fort Greely in Fort Clear in Thule Air Base na Grenlandiji) (po Conely, 2012, str. 20-23).

\subsection{Rusija}

Rusija je eden izmed najpomembnejših in zavzetih akterjev na Arktiki. To je tudi zaradi dejstva, da večina prebivalcev Arktike živi v arktični Rusiji in ima največjo površino v tej regiji - skoraj polovico ozemlja nad polarnim krogom. Območje v celoti ali delno vključuje ozemlja Republike Saha (Jakutija), provinci Murmansk in Arkhangelsk, ozemlje Krasnoyarsk, Nenci, Jamal-Nenets in avtonomno okrožje Chukchi. Pomen Arktike za Rusijo se razteza na geopolitično (edini zanesljivi dostop do morja), gospodarsko (naravni viri in logistično gre za najhitrejši prevoz blaga) ter varnostno področje. Rusija je prvi arktični narod, ki je oddal zahtevek za razširitev epikontinentalnega pasu za 1,2 milijona $\mathrm{km}^{2}$, vključno s severnim tečajem, ki ga je CLCS zavrnil (oddali prehitro). Kljub temu ga je leta 2001 znova vložila in v zahtevku, če bi ga odobrili, pridobila skoraj polovico Arktičnega oceana, vključno s severnim tečajem. CLCS predloga ni zavrnil, vendar ga tudi niso sprejeli. Rusija tako s svojo ambicioznostjo želi prevlado nad Arktiko, zaradi česar je tudi v sporu z nekaterimi sosedi arktične regije. Dva glavna ozemeljska spora sta za Lomonosov hrbet in severni tečaj (slika 1) (Benitah, 2007).

Zaradi Lomonosovega hrbta je Rusija v sporu s Kanado in Kraljevino Dansko. Leta 2007 je Rusija poskušala dokazati svoje trditve z raziskovalno odpravo in nalogo, da zbere vzorce vode in usedline. Hkrati so posadili tudi rusko zastavo za potrditev pravic do morskega dna pod severnim tečajem. Vzorce so predali CLCS kot dokaz, da Lomonosov hrbet spada v njihovo razširitev epikontinentalnega pasu. Spor o Lomonosovem hrbtu z njegovim energetskim potencialom in izrazito geografsko lego bi lahko v prihodnosti sprožil oborožene konflikte (Rozzof, 2009). Lomonosov hrbet se šteje za območje največjih energetskih virov in v tem smislu najpomembnejšo in najbolj nevarno območje v arktični regiji. Po mnenju nekaterih 
analitikov je spor težnja po reinkarnaciji imperialističnega razmišljanja ter dodaten znak vračanja geopolitičnega dejavnika pri načrtovanju in izvajanju zunanje politike (Filipović, 2010).

Interesi, cilji in ukrepi so zapisani v ruski strategiji Državna politika Ruske federacije na arktičnem območju do leta 2020 in nadaljnji obeti in jo je nekdanji predsednik Dimitrij Medvedjev sprejel leta 2008, vendar nam ne razkrije njenih namenov, temveč samo predstavi splošne smernice za njeno politiko v regiji. Kaže, da se bo Rusija lotila ugotavljanja problemov in približevanja na Arktiki iz vseh smeri. Čeprav priznava dvostransko in večstransko sodelovanje z drugimi arktičnimi državami, se na področju vojaške varnosti pripravljajo na ugoden operativen režim in vodenje potencialnih spopadov (Ruska federacija, 2009). Vojaška strategija Rusije za Arktiko je ena izmed najbolj kritičnih za prihodnost, vendar pa je le površno razložena. Gre za varovanje nacionalnih interesov pod različnimi pogoji vojaškega in političnega položaja in pomembnost ohranjanja potencialnega in potrebnega boja. Po mnenju ruskih oblasti ne gre za varovanje mej, temveč je primarni cilj vojaških priprav boj proti nezakonitim dejavnostim na morju, kot so terorizem, tihotapljenje, nezakonito priseljevanje in netrajnostna raba vodnih bioloških virov (Zysk, 2009). Nazadnje je omenjena potreba po ohranitvi miru in sodelovanja ter poudarek na mednarodnem sodelovanju. Lahko bi rekli, da ta del strategije kaže protislovje identifikacijo Arktike kot območja miru in sodelovanja ter hkrati področja vojaške varnosti (Heininen, 2012). Zaradi konfliktnih situacij je vloga Rusije v arktični regiji še vedno gledana $\mathrm{z}$ vojaške perspektive. Rezultat ruske arktične politike je povečana okrepitev mednarodne skupnosti na vojaško varnost. Na Rusijo se gleda kot na nepredvidljivega akterja, in čeprav sta mir in sodelovanje prisotna $\mathrm{v}$ ruski retoriki, kakršen koli namig na vojsko in njeno pristnost sproži mednarodna ugibanja o regijski militarizaciji v regiji (Zysk, 2009). Mednarodna skupnost je trenutno na precepu in njen odziv na rusko arktično politiko bo odločila o prihodnosti Arktike. Ruska arktična politika dokazuje spreminjajoči se geopolitični položaj na severu, s katerim hkrati poskušajo stabilizirati gospodarstvo v državi. Stabilizacija gospodarstva pomeni več korakov, ki bodo vodili Rusijo k ponovni pridobitvi vloge glavne regionalne moči in svetovnega energetskega akterja (Heininen, 2012).

\subsection{Kanada}

Med regionalnimi akterji ima Kanada najdaljšo obalo, ki meji na Arktiko. Njeno ozemlje se razširi do zemljepisne širine $84^{\circ} \mathrm{N}$ in je najsevernejše naselje na svetu. Kanadske sile so naseljene v bazi Alert $\left(82^{\circ} \mathrm{N}\right)$, ki leži na otoku Ellesmere. Z velikim arktičnim arhipelagom, ki meji na Grenlandijo (Dansko) in Aljasko (ZDA), ima država na obeh mejah nerešene spore (slika 1). Na vzhodu je vzrok spora otok Hans v središču kanala Kennedy, na zahodu pa zaradi morja Beaufort in severozahodnega prehoda. Zaradi krčenja polarnih ledenikov se za Kanado odpirajo nove gospodarske priložnosti, zato želi čim hitrejšo rešitev sporov (Mackrael, 2012).

Z Dansko sta bili v sporu zaradi morja Lincoln, ki leži severno od Grenlandije in otoka Ellesmere. Čeprav sta se že leta 1973 dogovarjali o pomorski meji med 
ozemljema, nista vključili morja Lincoln, za katerega sta dosegli dogovor komaj leta 2012; morska meja obsega enako razdaljo od obale Kanada in Danske. Na jugu morja Lincoln v kanalu Kennedy je za 1,3 km² otokov - otoki Hans, ki nimajo nobenega znanega ekonomskega pomena. Kljub temu nobeno pogajanje iz let 1973 in 2012 ni prineslo rešitve, domnevno zato, ker nobena država ne želi popustiti v strahu ogrozitve drugih arktičnih terjatev. Obe vladi tako pospešeno iščeta sprejemljivo rešitev, od katere je ena, da se otok razdeli po sredini (Mackrael, 2012). Drugi spor je z ZDA zaradi morja Beaufort, ki leži severno od Aljaske in Kanade. Državi se ne moreta dogovoriti o morski meji, saj si obe drugače razlagata sestavo meje: ZDA po načelu ekvidistance, Kanada pa se nanaša na pogodbo iz Sankt Peterburga med Rusijo in Veliko Britanijo iz leta 1825, ki določa mejo po 141. poldnevniku. Območje ima velik gospodarski pomen za oba akterja, saj pod morskim dnom ležita naftno polje in zemeljski plin. Ker ZDA ni ratificirala UNCLOS-a, je Kanada v boljšem položaju, saj lahko vloži zahtevek za podaljšanje ekonomske cone. Kljub temu je vprašanje, ali bodo ZN odobrili kanadski zahtevek zaradi vloge ZDA v OZN (Mackrael, 2012). Tretji spor z ZDA je zaradi severozahodnega prehoda in njegovega nadzora. Kanada trdi, da je prehod v njihovih teritorialnih vodah, s čimer bi plovila morala imeti potrebna dovoljenja obalne straže za tranzit (Byers, 2013). Druge države, predvsem ZDA, pa želijo in trdijo, da je območje del mednarodnih vod in da imajo »tuje ladje pravico do tranzitnega prehoda skozi ožine, ki presega pravico do prehoda $\mathrm{v}$ rednih teritorialnih vodah. Tako imajo pravico do tranzitnega prehoda tujih ladij skozi ožino brez dovoljenja obalne straže« (Byers, 2013). Kanadska vlada vidi dve možni rešitvi za rešitev spora: da pridobi ameriško podporo za priznanje prehoda kot dela kanadskih teritorialnih vod in jim ponudi izključno pravico do prostega prehoda za vojaške ladje in trgovske ladje; ali skupno upravljanje prehoda s podpisom dvostranskega sporazuma. Z drugo rešitvijo bi Kanada izgubila del suverenosti in dohodka (Lytvynenko, 2011, str. 12-13).

Kanada je od leta 2009 sprejela tri strateške dokumente o svojem položaju na Arktiki, ki so bili v veliki meri sestavljeni zaradi ruske odprave leta 2007. Leto 2007 je pospešilo željo po potrditvi statusa severnega naroda in suverenosti v arktični zunanji politiki. Način, kako to doseči, so prevzeli od Rusije in krepijo svojo vojaško prisotnost (Heininen, 2012, str. 13-17). Vojaška prisotnost je privedla do vojaških vaj na severnih ozemljih in prikaza nacionalne suverenosti in moči (po Lytvynenko, 2011, str. 10).

\subsection{Položaj evropskih držav}

Danska, Islandija, Norveška, Finska in Švedska so evropske države, ki tekmujejo za svoj del arktičnega ozemlja. Pri evropskih državah ne gre toliko za prikaz politične moči kot gospodarske koristi, ki jih prinaša lastništvo dela arktičnega ozemlja.

\subsubsection{Danska}

Danska ne leži v Arktičnem oceanu, a ima kljub temu interes v regiji, saj so deli danskega ozemlja tudi Ferski otoki in Grenlandija, ki so med Arktiko in Atlantskim 
oceanom, vzhodno od kanadskega arktičnega arhipelaga. To daje Danski mesto med arktičnimi akterji in jo vključuje med številne spore za ozemlje. Poleg že omenjenega spora s Kanado za morje Lincoln in otoke Hans je Danska leta 2004 podala zahtevek za lastništvo severnega tečaja (slika 1). V zahtevku trdijo, da je severni tečaj geološki del Grenlandije, s čimer spada pod upravljanje Danske. Tako bi postali tudi lastniki nedoločene količine nafte in zemeljskega plina. Grenlandija naj bi bila povezana s severnim tečajem z več kot $1240 \mathrm{~km}$ podvodnega gorovja, Lomonosovim hrbtom (spor z Rusijo). Formalni zahtevek še ni bil podan, počakali bodo, dokler raziskave ne bodo dokončane. Zanimivo je, da je Kanada prvič zahtevala lastništvo nad severnim tečajem v 50. letih. Mednarodno sodišče je razsodilo, da bo Kanada lastnica, če nobeden v 100 letih ne bo vložil zahtevka za njeno lastništvo (Coman, 2004).

Strategija Kraljevine Danske za Arktiko 2011-2020 podpira enakovrednost med podpisnicami strategije, torej Danske, Grenlandije in Ferskih otokov, ki poskušajo na novo opredeliti svoj globalni položaj. Štiri prednostna področja so zagotovitev večje pomorske varnosti in uveljavitev suverenosti in nadzora; izkoriščanje mineralnih surovin in uporaba obnovljivih virov energije ter ohranitev vodilne vloge v arktičnih raziskavah; pridobivanje znanja o podnebnih spremembah; in krepitev sodelovanja v Arktičnem svetu. Strategija poudarja pomen nacionalne varnosti in suverenosti, vendar poudarja tudi pomen Nata in drugih mednarodnih sodelovanj (Heininen, 2012, str. 17-22).

\subsubsection{Islandija}

Islandija je najmanj opazna država brez mejnih sporov in na prvi pogled brez večje ambicioznosti v arktični regiji. Brez svoje vojske (razen obalne straže) je bila do leta 2006 za svojo nacionalno varnost v celoti odvisna od ameriške vojske. Ko se je ameriška vojska umaknila, je zahtevo po obrambi nadomestil Nato, katere članica je Islandija. Tako je Islandija edina država, ki ne uveljavlja suverenosti z dodatnimi vojaškimi četami v arktični regiji. Ribištvo kot glavna industrijska panoga je edini večji interes. S taljenjem ledu je njen geografski položaj odprt za nove okoliščine, v katerih bi Islandija lahko igrala veliko vlogo v pomorskem prometu (Heininen, 2012, str. 30-33).

\subsubsection{Norveška}

Norveška je z arktično obalo in neposrednim dostopom do morja poseben primer med evropskimi arktičnimi državami. Trenutno nadzoruje le območje v ekonomski coni, ki vključuje ribolovni območji v okolici Svalbarda in Jan Mayena, a je zaradi potenciala svoje ekonomske cone že dvakrat zavrnila članstvo v EU, saj je noče deliti s članicami EU. Svojo uradno predložitev za razširitev meje epikontinentalnega pasu je podala leta 2006 in se razteza na tri območja: Loop Hole v Baretsovem morju, bazen Nansen in Banana Hole (po Isted, 2009, str. 360). Pozneje je komisija ugotovila, da se zahtevka Norveške in Rusije nad delom v Barentsovem morju prekrivata. Prekrivajoči se zahtevek sta državi rešili z diplomatskim pogajanjem, ki je privedlo do mirne rešitve. Rusija in Norveška že desetletja urejata svoje spore diplomatsko, 
na primer s sporazumom iz leta 1976, ki ureja ribolov v Barentsovem morju, in z ustanovitvijo skupne komisije za ribištvo. Sodelujeta tudi na raziskovalnem področju (Norveška sama porabi okoli 200 milijonov dolarjev), njuno sodelovanje pa temelji na okoljskih vprašanjih in posledicah podnebnih sprememb v arktični regiji in na potencialnih virih za vrtanje nafte (Honneland, 2007, str. 9). Zato je izbruh med Norveško in Rusijo malo verjeten, saj s sodelovanjem pleteta soodvisnost na območju Arktike.

\subsection{4 Švedska}

Tudi Švedska aktivno sodeluje v večstranskem ali dvostranskem procesu v regiji. Leta 2011 je švedska vlada sprejela strateški dokument, v katerem opredeljuje glavne interese in uradno politiko države na Arktiki. V njem je zapisala, da bo kljub velikim potencialom za gospodarske priložnosti regija soočena s številnimi izzivi, ki so večinoma povezani s podnebnimi spremembami. Zaradi večjega vpliva se je Švedska lotila aktivne vloge pri oblikovanju arktične politike EU in je skupaj s Finsko most med EU in arktično regijo. Čeprav sama nima neposrednega dostopa do Arktičnega oceana, se država vključuje v sodelovanje z drugimi državami kot ponudnik storitev - znanje o lomljenju ledu. Prav tako so njene podnebne in okoljske raziskave imele ogromen znanstveni vpliv pri razumevanju podnebnih sprememb v regiji in po svetu. Prilagajanje na podnebne spremembe zahteva dobro znanje o njihovih učinkih, ne samo o bioloških in tehničnih, temveč tudi na skupnosti in na ljudi. Vse to jim pomaga pri uresničevanju interesov, ki se delijo na politične, gospodarske in varnostne. Gospodarski interesi so opredeljeni kot širjenje gospodarskega sodelovanja in možnosti. Politični interesi so, da je treba vsa morebitna vprašanja in konflikte reševati na mednarodni platformi in jih mirno rešiti. Varnostni interesi so opredeljeni v smislu, da želi, da regija ostane z nizkim tveganjem za izbruh konfliktov. Vendar pa so okoljska vprašanja pomembna tudi kot potencialni problem varnosti, ki jih podnebne spremembe neizogibno prinašajo (Government Offices of Sweden, 2011).

\subsubsection{Finska}

Podobno kot Švedska je tudi Finska brez neposrednega dostopa do Arktičnega oceana. Kljub temu ima politične, gospodarske in varnostne interese v regiji, pri čemer sta primarna interesa gospodarstvo in okolje. Od leta 1990 je Finska dejavna v okoljskih zadevah, predvsem glede onesnaževanja okolja Arktike, ki prihajajo iz Murmanska v Rusiji. Stara sovjetska tehnologija ima slab vpliv na okolje in Finska kot njena soseda je začela več platform za obravnavo varstva okolja na Arktiki. Kljub veliko uspešnih pobud v regiji Finska ni nikoli pokazala interesa, niti ni bila dejavna v mednarodnem arktičnem sodelovanju. Njena strategija za Arktiko, ki je izšla leta 2010, se osredotoča na štiri točke: okolje, gospodarske dejavnosti in prenos znanja, infrastruktura in promet ter avtohtono ljudstvo. Finska kakor tudi Švedska je del EU in s tem obe državi podpirata Arktično politiko EU in se zavzemata za vključitev EU kot članici opazovalki v Arktičnem svetu. Finski cilji so opozoriti na posebne značilnosti in možna tveganja, povezana s podnebnimi spremembami, ter 
se ponuditi kot ponudnik storitev - prometne poti in infrastruktura. Finska se zaveda svoje omejene moči in možnosti, zato skupaj s Švedsko želi, da bi EU prevzela bolj aktivno vlogo v institucijah Arktičnega sveta in političnih vprašanjih v arktični regiji kot močnejši akter in bi se zavzemala za finske interese v mednarodni areni (Government of Finland, 2013).

Sklep Ameriški oblikovalci politik so že pred leti predstavili svet kot veliko šahovnico, ki je razdeljena na štiri regije, in sicer na Rusijo, Evropo, Bližnji vzhod in Azijo, peti del pa je postala Arktika. Ali je to dobro ali slabo za mednarodno skupnost, še ni določeno. Trenutno je izbruh konflikta še omejen, saj otežena dostopnost do regije preprečuje raziskave, ki bi objektivno ocenile energetske zaloge. Kljub temu države, kot je Rusija, razmišljajo za prihodnost (»incident« leta 2007), saj bi predčasna zagotovitev ozemlja in poznejša najdba energentov omogočili državi gospodarsko prednost in politično moč v mednarodni skupnosti in na mednarodnem energetskem trgu. Čeprav države trenutno delujejo skozi mednarodni pravni okvir političnih in gospodarskih povezav, sodelovanja ter zgodovinskih zahtevkov, to ne zmanjšuje povečanja vojaške prisotnosti v regiji. Kanada, Danska, Norveška, Rusija in ZDA povečujejo zračne, morske in kopenske zmogljivosti in napovedujejo še dodatno povečanje. Vse so oborožene s plovili, letali in orožjem, s katerimi bodo, če bo treba, branile svojo suverenost in interese. To ne pomeni, da so države edini akterji v regiji, temveč predstavljajo glavne mogoče pobudnike izbruha konfliktov. Na podlagi aktualnih podatkov, strategij in zgodovinskih zahtevkov se bo prihodnji razvoj delil na tri kategorije: mednarodni odnosi, vprašanje mednarodnega prava in varnost, ki se med seboj prepletajo na mednarodni platformi. Sodelovanje med državami in razvoj kooperativnega modela varnosti v arktični regiji bo nemogoč, če bodo ZDA še naprej pritiskale na Rusijo in prepričevale države članice Arktičnega sveta in članice Nata, delovanja proti njej. Če se bo razvila politika »zadrževanja« (angl. containment policy), ${ }^{11}$ je mogoče, da bo Rusija odgovorila z agresijo. Državi sta bili v vseh konfliktih v zgodovini nasprotnega mnenja, kar povečuje možnost, da se bo ob izbruhu konflikta ponovno uvedla blokovna razdelitev. Ob tem izidu si bosta državi, skupaj z zavezniki, poskušali zagotoviti čim večji del ozemlja, bogatega z energenti, in si tako zagotoviti čim večjo gospodarsko in politično moč za naslednje stoletje. Že zdaj je opazno, da so geopolitični interesi postali znova velik del zunanje politike držav, ki se izražajo pasivno - ZDA poskuša uresničiti svoje interese s pomočjo partnerjev ali aktivno - Rusija ima neposreden, neomajen in celo agresiven pristop. Rusija je edina država, ki »igra svojo igro« (izzivalni manevri), a brez potrebne tehnologije za nadaljnje raziskave. Verjetno se bo odločila za sodelovanje z drugimi arktičnimi državami, ki imajo potrebno znanje za vrtanje $\mathrm{v}$ globokih vodah in $\mathrm{v}$ hladnih razmerah, česar ruskim raziskovalnim centrom zelo primanjkuje. Kljub ruski potrebi po sodelovanju se lahko ob povečanem pritisku ZDA na njenih mejah (Natova prisotnost) odloči za terjatev ozemlja s pomočjo vojske, brez njenega sodelovanja na mednarodni platformi, s povečano militarizacijo regije, novimi viri napetosti ter dolgoročno nestabilnost

\footnotetext{
"S Strateška zunanja politika, ki so jo ZDA izvajale v poznih 40. letih in v začetku leta 1950, da bi preprečili ekspanzivno politiko Sovjetske zveze.
} 
arktične regije. Čeprav ruska dejanja s povečano militarizacijo niso pozitivna poteza za prihodnost, pa ni edina država, ki je povečala svojo vojaško moč v regiji, sledita ji Kanada in Danska. Kanadska strategija je vzpostaviti vojaški center za usposabljanje na tem območju in povečati svojo prisotnost na morju. Kot Rusija se tudi Kanada pripravlja na poslabšanje odnosov med državami in boj za ozemlje. Predvsem jo skrbi poslabšanje odnosov z Rusijo zaradi Lomonosovega hrbta in z ZDA zaradi otokov Hans ter severozahodnega prehoda. Evropski regionalni akterji Danska, Islandija, Norveška, Švedska in Finska si večinoma želijo mirno, varno in zanesljivo Arktiko. Svoje interese želijo uresničevati s sodelovanjem z velesilama in skozi visoko razvita tehnološka podjetja, ki imajo sposobnost, da prodrejo do naravnih virov. Eno takih podjetij je naftna družba Statoil (Norveška), ki ima edina na svetu vzpostavljen proizvodni obrat za črpanje zemeljskega plina nad arktičnim krogom. Prav tako imajo Norveška, Švedska in Finska rešena vsa večja odprta vprašanja in prejšnje mejne težave z Rusijo. Kljub temu ne podpirajo militarizacije V regiji, temveč reševanje odprtih vprašanj pravno in s sodelovanjem v Arktičnem svetu, kar bi moralo postati primarno pravilo za reševanje vseh problemov, vključno z varnostnimi vprašanji. Danska je edina med evropskimi državami, ki ima v svoji strategiji tudi cilje za vidno vojaško prisotnost, s poudarkom na pomembnosti dolgoročnega političnega dogovora o obrambi (analiza oboroženih sil in njihove prihodnje naloge na Arktiki). Islandija je edina država, ki je skoraj v celoti odvisna od njenega sodelovanja $\mathrm{z}$ drugimi akterji v regiji.

Na podlagi vseh pridobljenih podatkov postavljene hipoteze: »Na podlagi preteklih dogodkov in obljube bogastva $\mathrm{v}$ lastništvu arktičnih energentov si bodo države poskušale na silo, z vojsko, zagotoviti čim večje lastništvo arktičnega ozemlja«, še ni mogoče objektivno potrditi ali ovreči. Izhodišče je odnos med Rusijo in ZDA, pri čemer nam pretekli dogodki ne prikazujejo pozitivnega izida (npr. hladna vojna). Prav tako se pojavlja ovira, ko želimo ovreči hipotezo: preoblikovanje moči v mednarodni skupnosti. Predvsem Rusija si želi povrniti vojaško in energetsko moč, ki jo je doživela z upadom geopolitične moči leta 1991 ob razpadu SZ. Potrditev moči v mednarodnih in evrazijskih geopolitičnih zadevah si poskuša zagotoviti predvsem z energenti: vedno večji izvoz energentov v evropske države, da se tako vpliva na tuje gospodarske politike. Energetska tekma za Arktiko je le naslednji evolucijski korak od tekme za pristanek na Luno ali oboroževalne tekme. Zaradi analiz, da se energetska poraba povečuje, medtem ko se zaloge zmanjšujejo, je odkritje novih virov nafte urgentno. Arktika predstavlja vir, ki si ga je mogoče razdeliti in v »miru izkoriščati«. Toda da si države zagotovijo del arktičnega ozemlja, morajo izkoristiti vso pravno podlago ter hitrost in prebrisanost pri njenem zavzetju. Brez razvoja tehnologije za vrtanje je na Arktiki zagotovljeno sodelovanje med akterji, ko bo tehnologija dostopna in brez rešitve sporov na omenjenih območjih, pa bo militarizacija prišla do večje izrazitosti. Hkrati pa se morajo države tudi zavedati vprašanja okoljske varnosti, ki navsezadnje lahko ogrozi vsa njihova prizadevanja. Ali cilj presega sredstva za njeno uresničitev? Odgovor na to vprašanje bomo dobili čez nekaj let. 


\section{Literatura}

1. Arctic Governence Project. 2015. http://www.arcticgovernance.org/, 4. 11. 2015.

2. Bailey, J. 2009. The Facts on File Dictionary of Ecology and the Environment. Infobase Publishing: New York. https://books.google.si/books?id=77L1O7hefV0C\&dq=the+facts + $o n+$ file + dictionary $+o f+e c o l o g y+$ and + the + environment $\& h l=s l \&$ source $=g b s \_n a v l i n k s \_s$, 4. 11. 2015.

3. Benitah, M. 2007. Russia's Claim in the Arctic and the Vexing Issue of Ridges in UNCLOS. V American Society of International Law 11-27. http://www.asil.org/insights/ volume/11/issue/27/russias-claim-arctic-and-vexing-issue-ridges-unclos, 4. 11. 2015.

4. Byers, M. 2013. Canada's Arctic nightmare just came true: The Northwest Passage is commercial. Globe and Mail: Toronto. http://www.theglobeandmail.com/globe-debate/ canadas-arctic-nightmare-just-came-true-the-northwest-passage-is-commercial/ article14432440/, 15. 8. 2015.

5. Carlson, D. J. 2009. The Scramble for the Arctic: The United Nations Convention on the Law of the Sea (UNCLOS) and Extending National Seabed Claims. University of California: Merced. http://works.bepress.com/cgi/viewcontent.cgi? article $=1028 \&$ context =jondcarlson, 20. 10. 2015.

6. Chapman, B. 2011. Geopolitics: A guide to the Issues. Contemporary military, strategic and security issues. Oxford: Praeger.

7. Cinelli, C. 2011. The Law of the Sea and the Arctic Ocean. Arctic Review on Law and Politic. 2-1, str. 4-24. http://site.uit.no/arcticreview/files/2012/11/AR2011-1_Cinelli.pdf, 15. 8. 2015.

8. Coman, J. 2004. Denmark causes international chill by claiming North Pole. The Telegraph: United States. http://www.telegraph.co.uk/news/worldnews/1474377/ Denmark-causes-international-chill-by-claiming-North-Pole.html, 4. 11. 2015.

9. Council of European Union. 2014. Council conclusions on developing a European Union Policy towards the Arctic Region. Foreign Affairs Council meeting: Brussels. http://www. consilium.europa.eu/uedocs/cms_data/docs/pressdata/EN/foraff/142554.pdf, 20. 8. 2015.

10. Conley, H., A. Osthagen, T. Toland in J. Kraut. 2012. A New Security Architecture for the Arctic. Center for Strategic and International Studies: Washington. http://csis.org/files/ publication/120117_Conley_ArcticSecurity_Web.pdf., 22. 8. 2015.

11. Evers, M. 2013. Northeast Passage: Russia Moves to Boost Arctic Shipping. Spiegel Online International. http://www.spiegel.de/international/world/russia-moves-to-promotenortheast-passage-through-arctic-ocean-a-917824.html, 22. 8. 2015.

12. Filipović, M, 2010. Teritorijalno razgraničenje na Arktiku. Vojno delo: Beograd. http:// www.odbrana.mod.gov.rs/odbrana-stari/vojni_casopisi/arhiva/VD_2010-leto/07.\%20 Teritorijalno\%20razgranicenje\%20na\%20Arktiku,\%20Filijovic\% $\%$ 20M.pdf. 13. 8. 2015.

13. Georgescu, I. 2010. Arctic Geopolitics - time for a New Regime. Institut Europeen des hautes etudes internationals. http://www.ie-ei.eu/IE-EI/Ressources/file/memoires/2010/ Georgescu.pdf, 23. 8. 2015.

14. Government of Finland. 2013. Finland's Strategy for the Arctic Region. Prime Minister's Office Publications: Helsinki. http://vnk.fi/documents/10616/334509/ Arktinen+strategia+2013+en.pdf/6b6fb723-40ec-4c17-b286-5b5910fbecf4, 23. 8. 2015.

15. Government Offices of Sweden. 2011. Sweden's Strategy for the Arctic Region. Department for Eastern Europe and Central Asia: Stockholm http://www.government.se/ contentassets/85de9103bbbe4373b55eddd7f71608da/swedens-strategy-for-the-arcticregion, 22. 8. 2015.

16. Heininen, L. 2012. Arctic Strategies and Policies: Inventory and Comparative Study. The Northern Reasearch Forum \& The University of Lapland: Iceland. http://www.rha. is/static/files/NRF/Publications/arctic_strategies_7th_draft_new_20120428.pdf., 23.8. 2015.

17. Honneland, G. 2007. Norway and Russia in the Barents Sea: Cooperation and Conflict in Fisheries Management. VMatthias Neumann ur. Russian Analytical Digest, 9-11. 
18. Isted, K. 2009. Sovereignty in the Arctic: An Analysis of Territorial Disputes and Environmental Policy Considerations, Journal of Transnational Law and Policy 18(2): Florida State University.

19. Keil, K. 2011. U.S. Waking Up to Arctic Resources? The Arctic Institute: Saint Petersburg. http://www.thearcticinstitute.org/2011/08/us-waking-up-to-arctic-riches.html. 18. 8. 2015.

20. Koivurova, T., J. Kapyla in H. Mikkola. 2015. Continental shelf claims in the Arctic: Will legal procedure survive the growing uncertainty? V FIIA Briefing Paper 178. The Finnish Institute of International Affairs: Helsinki. http://www.fiia.fi/en/publication/516/ continental_shelf_claims_in_the_arcticl, 21.8.2015.

21. Lytvynenko, A. 2011. Arctic Sovereignty Policy Review. Government of Canada. http:// www4.carleton.ca/cifp/app/serve.php/1355.pdf., 20. 8. 2015.

22. Parker, G. 1997. Zahodna Geopolitična misel v dvajsetem stoletju. Ljubljana: FDV.

23. Mackrael, K. 2012. Canada, Denmark closer to settling border dispute. V The Globe and Mail: Toronto. http://www.theglobeandmail.com/news/national/canada-denmark-a-stepcloser-to-settling-border-dispute/article5831571/, 17. 8. 2015.

24. National Security Council. 2009. National Security Presidential Directive 66. http://fas. org/irp/offdocs/nspd/nspd-66.htm, 20.8.2015.

25. Ruska federacija. 2009. Basics of the State Policy of the Russian Federation in the Arctic for the Period till 2020 and for the Future Perspective. Rossiyskaya Gazeta: Moscow. http://arcticgovernance.custompublish.com/russia-basics-of-the-state-policyof-the-russian-federation-in-the-arctic-for-the-period-till-2020-and-for-a-furtherperspective.4651232-142902.html, 21. 8. 2015.

26. The Pew Charitable Trusts. 2015. What is the Arctic. http://oceansnorth.org/what-arctic, 25. 8. 2015.

27. United Nations. 2013. United Nations Convention on the Law of the Sea, sprejeta 10. decembra 1982. http://www.un.org/depts/los/convention_agreements/convention_ overview convention.htm, 19.8.2015.

28. United States Government. 2013. National Strategy for the Arctic Region. The White House: Washington. http://www.whitehouse.gov/sites/default/files/docs/nat_arctic strategy.pdf, 20. 8. 2015.

29. U.S. Department of Commerce. 2013. What is the law of the sea? National Oceanic and Atmospheric Administration. http://oceanservice.noaa.gov/facts/lawofsea.html, 16. 8. 2015.

30. Zysk, K. 2009. Russian national security strategy to 2020. Joint Force Quarterly, NDU Press. http://www.ndu.edu/press/lib/images/jfq-57/zysk.pdf, 15. 8. 2015. 
Slika 1: Arktična regija in ozemeljske

terjatve

Figure 1: Arctic territorial claims

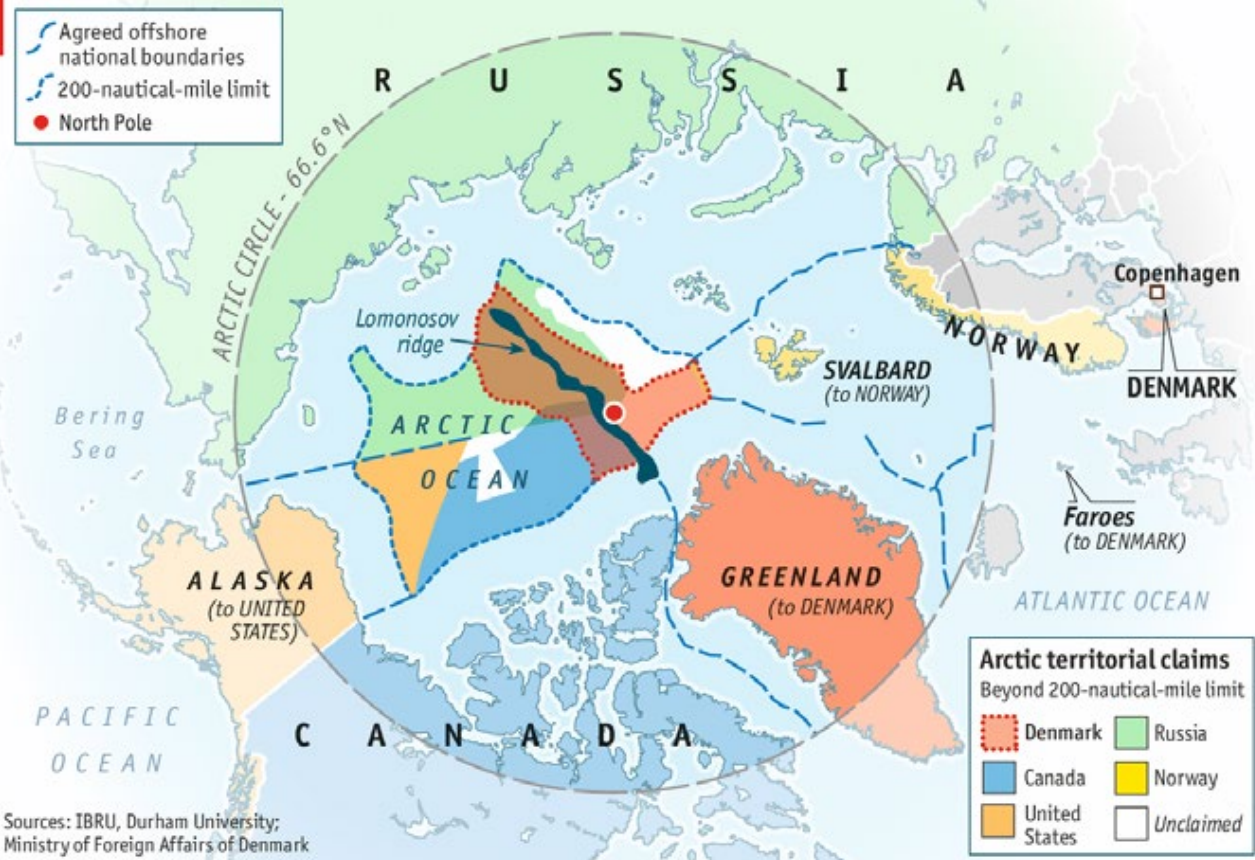

Severozahodni

in severovzhodni

prehod

Figure 2:

Northwest and northeast passages

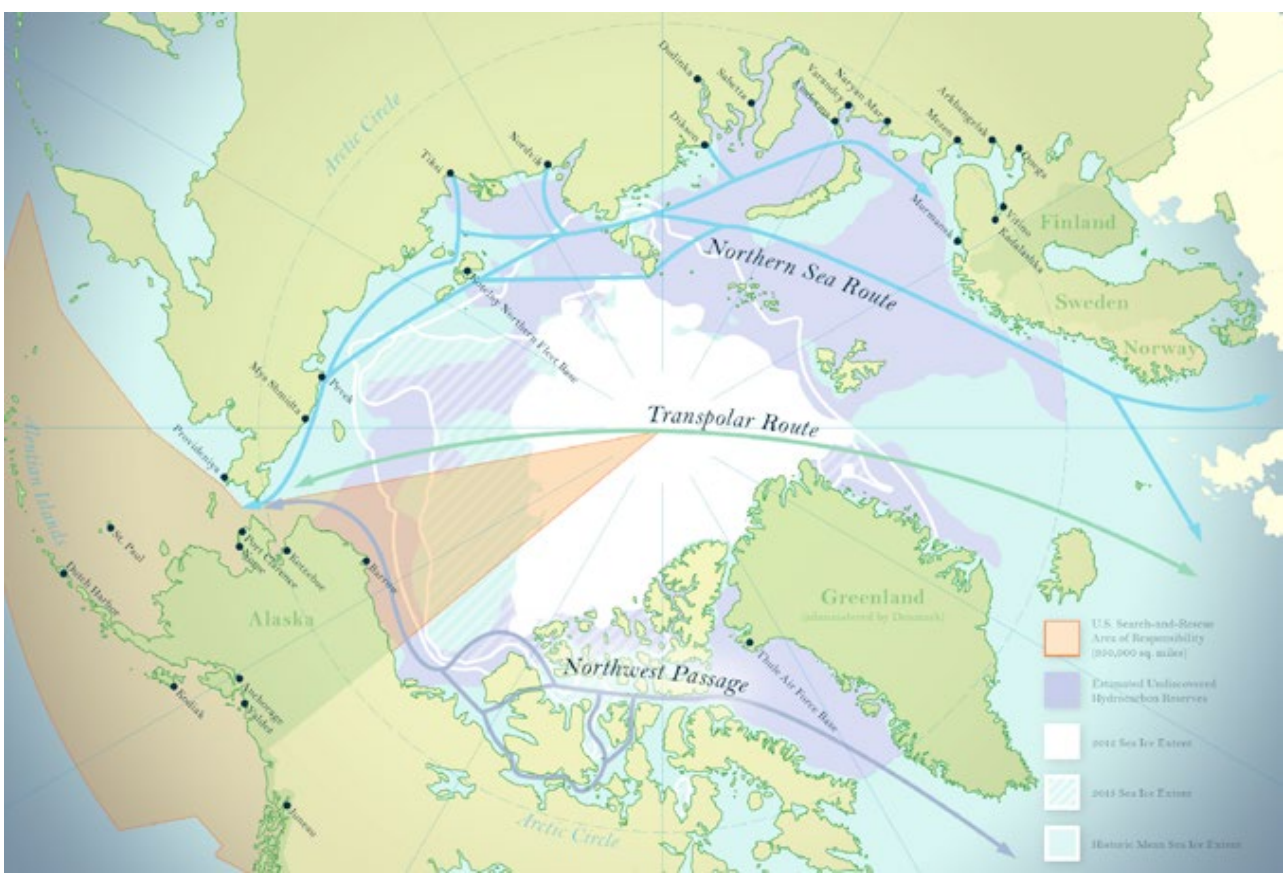

